\title{
OBTENÇÃO DE ÍNDICES DE REFRAÇÃO DE MINERAIS COM AUXÍLIO DE RAIOS
}

LASER

J.B.de Madureira Filho ${ }^{1}$

W.H.Kerth Junior ${ }^{2}$

A determinação de índices de refração de substâncias minerais pode ser conseguida por meio de uma série de diferentes técnicas já consagradas pela literatura mineralógica (NESSE, 1986). A escolha da melhor técnica ficará sempre na dependência do grau de precisão que se deseja obter e das características físicas das amostras estudadas. A maioria destas técnicas usa a luz policromática ou a monocromática (sódio) como fonte de energia para a obtenção dos seus resultados. Convém salientar que os componentes do feixe luminoso, mesmo no caso monocromático, não apresentam coerência (KERR, 1959) no caminhamento de suas frentes de onda ao longo do movimento ondulatório da luz. Tal fato provoca uma pequena difusão da luz, causando a redução na precisão conseguida em algumas técnicas analíticas, por exemplo, aquela baseada na lei de Brewster (AFONSO \& FINN, 1972).

No presente trabalho, retoma-se a determinação de índices de refração a partir do ângulo de Brewster, usando-se como fonte de energia a luz laser (Light Amplification by Stimulated Emission of Radiation). Aqui, ao contrário da luz comum, o feixe monocromático da luz laser possui altíssima sintonia de fase ao longo do seu percurso, facilitando a obtenção precisa do ângulo de polarização máxima.

A polarização máxima se dá sempre que os raios refletido e refratado são perpendiculares entre si e, neste caso, aplicando-se a lei de Snell tem-se que o índice de refração é igual à tangente de ângulo de incidência.

Para maior precisão na determinação do ângulo de Brewster, a amostra é

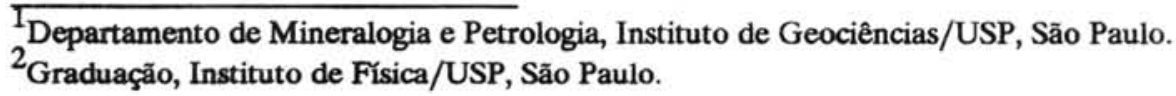


montada na parte central do disco horizontal de um goniômetro de reflexão com nônio (Webster, 1983). A amostra deve ser colocada de tal modo a superfície de incidência fique na posição vertical. O feixe refletido dessa superfície deve passar por uma placa de polaróide e atingir uma célula fotoelétrica que, por sua vez, está ligada a um microamperímetro.

O ângulo de máxima polarização é conseguido quando o raio refletido polarizado for totalmente absorvido pelo polaróide. O microamperímetro, conseqüentemente, não acusará passagem de corrente.

Os resultados estão sendo obtidos no laboratório de óptica do Instituto de Física da USP. Os materiais estudados até o presente, são: vidro, granada, quartzo, calcita, magnetita e hematita.

O andamento da pesquisa permite antecipar algumas conclusōes: a) a qualidade do polimento da superfície de incidência é fundamental para obtenção de bons resultados; b) o valor do índice obtido é aquele contido no plano de incidência do laser; c) a precisão poderá chegar à terceira casa decimal; d) o método aplica-se a minerais transparentes, translucidos e opacos; e) podem estar na forma de cristais, fragmentos de cristais, seções delgadas, seções polidas e gemas lapidadas. A Tabela 1 compara os resultados obtidos com aqueles encontrados na literatura.

\section{REFERÊNCIAS BIBLIOGRÁFICAS}

ALONDO, M. \& FINN, E.J. (1972) Física: um curso universitário. São Paulo, Edgard Blücher. 565p.

KERR, P.F. (1959) Optical Mineralogy. 3ed. New York, McGraw Hill. 442p.

NESSE, W.D. (1986) Introduction to Optical Mineralogy. New York, Oxford University Press. 325 p.

WEBSTER, R. (1983) Gems-their sources, descriptions and identification. 4 ed. London, Butterworths. 1006p. 
Tabela 1 - Valores de índices de refração obtidos com laser comparados aos da literatura.

vidro

granada

quartzo

calcita

magnetita

hematita
Literatura

IR Laser

1,518

1,790

$1,544-1,553$

$1,658-1,486$

2,42

$3,15-2,87$
1,510

1,791

1,539-1,549

$1,642-1,470$

2,10

$3,10-2,82$ 